\title{
The Mediating Role of Stress on the Effect of Self-Control and Self-Management on Level of Hope in Coaches
}

\author{
Serdar Sucan $^{1}$ \\ ${ }^{1}$ Erciyes University, Kayseri, Turkey \\ Correspondence: Serdar Sucan, Erciyes University, Kayseri, Turkey. E-mail: sesucan@hotmail.com
}

Received: February 20, 2019

Accepted: March 11, 2019 Online Published: March 25, 2019

doi:10.5539/jel.v8n2p279

URL: https://doi.org/10.5539/jel.v8n2p279

\begin{abstract}
The aim of this study was to the role of stress on the effect of self-control and self-management on hope level in coaches. The research population consisted of 196 (80 females, 116 males) physical education teachers working in schools in Kayseri. Participants were administered the Self-Control and Self-Management Scale (SCMS), Perceived Stress Scale (PSS-10) and Adult Hope Scale (AHS). As a result of the correlation analysis, there was a positive and significant relationship between the self-control and self-management skills and level of hope scores of the coaches $(p<0.01)$. In addition, there was a high and negative correlation between self-control and self-management skills and perceived stress scores of coaches $(p<0.01)$. As a result of the regression analysis, the level of hope of the coaches on self-control and self-evaluation; on the level of self-control and self-assessment of coaches; The perceived stress of the coaches was a significant predictor of the level of hope $(\mathrm{p}<0.01)$. In conclusion, this study showed that perceived stress directly affects self-control and self-management.
\end{abstract}

Keywords: coaches, stress, hope, self-control, self-management

\section{Introduction}

Barrow (1977) defined leadership as, "the behavioural process of influencing individuals and groups towards set goals. Leadership is an effective process for achieving group activities" (Bass, 1985). Leadership in sport is to set goals in the team, how to achieve these goals, and to determine responsibilities and roles (Anshel, 1977). The person who sets targets within the group is naturally a leader candidate. Therefore, the coach is the effective leader. Therefore, the trainer should be able to develop and teach the skills (Yukl, 1981).

In order for the athletes to be successful, they must perform good training and technical-tactical work. For this reason, athletes need a good coach. The coach is the person who directs, runs and prepares the athletes by combining theoretical knowledge and experience (Doğan, 2004). This puts a lot of pressure on coaches and causes them to experience stress in business life (Budak \& Sürgevil, 2005). Coaches work more efficiently when they check the stress level.

Stress is a condition that occurs when the organism is physically and psychologically threatened and forced (Baltaş \& Baltaş, 2002). Stress is a psychologically stressing process that affects human physical and health status (Güney, 2001). The right direction of stress encourages the person to achieve hope and goals. Stress is an early warning system in situations that threaten happiness, health, trust, self-esteem and thought. When it is not controlled, it may cause illness, deterioration and death (Norfolk, 1989).

According to Kanfer and Kaoly (1972), human behavior is influenced by the environmental conditions. Self-control and self-management is an attempt to use self-control and self-management as a means of managing people's behavior and breaking the environmental control mechanism. Self-control and self-management, serves as a feedback system and involves three subsystems: self-monitoring (SM), self-evaluation (SE) and self-reinforcement (SR). In SM, the individual monitors the status and content of target behaviors. In SE, individual target behavior is compared with the internal standard of this behavior and problems are identified. In $\mathrm{SR}$, the individual rewards or punishes himself as open or closed. The focus of attention is redirected and the current and expected conditions are evaluated. The behavior is maintained or altered by the individuals effort towards internal agencying. These skills are the basic self-regulatory processes that can be applied to provide self-control. Rehm (1977) examined the relationship between self-control model and depression. In a later 
study, identified further subskills, such as attributional processes and goal setting (Kanfer \& Schefft, 1988). Bandura's (1991) social cognitive theory, presupposes that human behavior is motivated and regulated by the individual cognitive capacity to exert self-influence. Self-regulation is a multifaceted phenomenon that drives individual thoughts, affects and actions. The attention paid to emotions, thoughts, as well as to the conditions in and its effects, produces information that allows individuals to assess their development towards the target. The self-evaluation process consists of personal judgments of right or wrong, as a fundamental condition of managing existing activities (Simsek, Heavey, \& Veiga, 2010).

Hope is a positive motivation for the relationship between motivation and methods of achieving a goal. The methods of achieving the purpose are the claim that the person can produce appropriate methods to achieve his or her aim (Snyder, Rand, \& Sigmon, 2002). Those with high levels of hope, assume that there are many methods to achieve their goals (Snyder et al., 1991). It was found that the level of hope is directly proportional to performance, physical and psychological health (Snyder et al., 2002; Vilaythong et al., 2003). It is also said that hopeful thinking is important to solve psychological problems and to increase psychological resilience (Bilge et al., 2009).

This feature of hope is important in reducing the problem before and after the problem occurs. The aim of this study was to investigate the mediating role of stress in the self-control and self-management skills of physical education teachers in Kayseri.

\section{Method}

2.1 Participants and Study Design

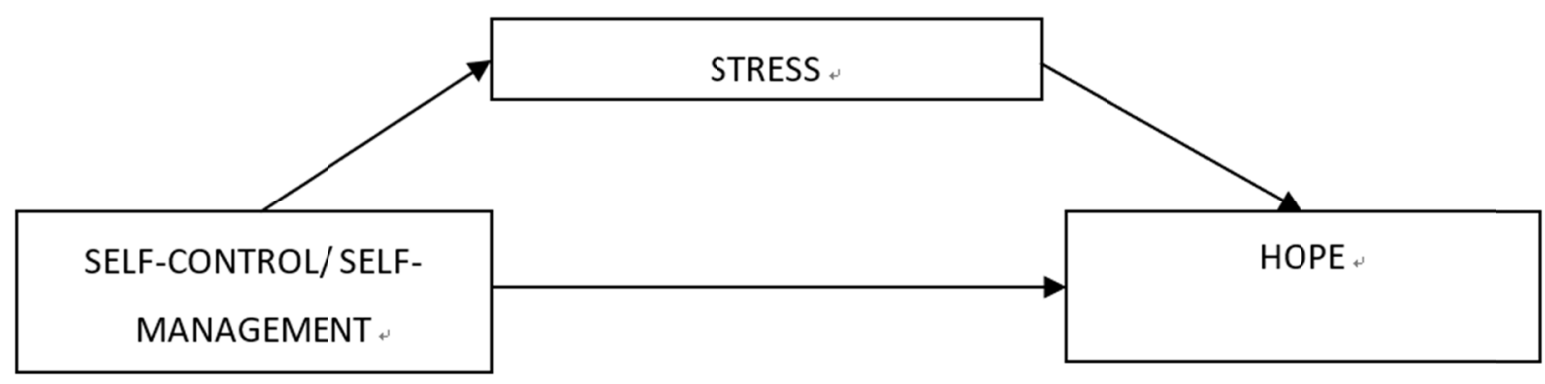

Figure 1. The research model

Coaches work more efficiently when they control stress. Therefore, it was investigated how the control of the stress experienced by the team or the athletes they work on might affect the coaching performance. The research population consisted of 311 physical education teachers working in schools in Kayseri. From the 311 individuals, 208 people were reached by simple random sampling method. As a result of validity and reliability analysis, 196 people were included in the study. 
Table 1. Demographic characteristics of the participants $(n=196)$

\begin{tabular}{llll}
\hline Variables & Categories & $\mathrm{f}$ & $\%$ \\
\hline Age (years) & $18-30$ years & 31 & 15.8 \\
& $31-40$ years & 77 & 39.3 \\
& $41-50$ years & 59 & 30.1 \\
51-60 years & 21 & 10.7 \\
Gender & 61 years and over & 8 & 4.1 \\
& Female & 80 & 40.8 \\
Education level & Male & 116 & 59.2 \\
& College & 92 & 46.9 \\
Working Year & Faculty & 74 & 37.8 \\
& Graduate & 30 & 15.3 \\
& $1-5$ year & 28 & 14.3 \\
& 6-10 year & 29 & 14.8 \\
Coaching Year & $11-15$ year & 58 & 29.6 \\
& $16-20$ year & 48 & 24.5 \\
& 21 year and over & 33 & 16.8 \\
& $1-5$ year & 51 & 26.0 \\
& 6-10 year & 44 & 22.4 \\
& $11-15$ year & 39 & 19.9 \\
& 16-20 year & 39 & 19.9 \\
& 21 year and over & 23 & 11.7 \\
\hline
\end{tabular}

In Table 1, approximately one third $40.8 \%$ of the coaches who participated in the research are female and two thirds $59.2 \%$ are male coaches. While $46.9 \%$ of the participant coaches had college education, $29.6 \%$ of the coaches worked for 11-15 years in the school they are currently working.

\subsection{Instruments}

\subsubsection{Perceived Stress Scale (PSS-10)}

The Perceived Stress Scale (PSS)-10 item version was developed by Cohen et al. (1983) to measure the individual's appraisals of stressful life events (Cohen et al., 1983). Its validity and reliability studies were performed by Erci (2006) and Bilge et al. (2009) and were then adapted to Turkish society. Items were designed to reveal the degree to which respondents found their lives unpredictable, uncontrollable, and overwhelming in the last one month. The PSS-10 is a five-point Likert scale ranging from $(0=$ never to $4=$ very often). There are four reverse items which are written positively (items 4, 5, 7 and 8). Total scores range from 0 to 40 with higher scores indicating higher perceived stress. The internal consistencies of the original scale change from 0.75 to 0.86 . In the present study PSS- 10 had internal consistency (Cronbach's alpha) of $\alpha=0.71$.

\subsubsection{Adult Hope Scale (AHS)}

The Adult Hope Scale developed by Snyder et al. (1991) includes 12 questions for individuals aged 15 years and over. Likert type four digits $(1=$ otally wrong and totally true $=4)$. So, the scores range will be between 8 and 32 . 4 questions are about the bus in operation, 4 questions are diversion and other questions are not scored. Total scores of subscales of the bus will constitute the overall score of hope. The higher the scores, the greater the hopes. The Cronbach alpha reliability coefficient of the scale was calculated to be 0.73 . In the present study AHS had internal consistency (Cronbach's alpha) of $\alpha=0.75$.

\subsubsection{Self-Control and Self-Management Scale (SCMS)}

SCMS, the original form developed by Mezo (2009), was adapted to Turkish culture by Akın, Demirci and Çardak (2012). The scale consists of six-point Likert type and 16 items. Total scale score range is $0-80$ on the SCMS, 0-30 on the Self-Monitoring Subscale (SMS), and 0-25 on each of the Self-Empowerment Subscale (SRS) and the Self-Assestment Subscale (SES). The Cronbach alpha reliability coefficient of the scale was calculated to be 0.80 . In this study, the Cronbach alpha internal consistency coefficient was 0.76 . High scores indicate high levels of self-control and self-management.

\subsection{Data Analysis}

The data obtained in the research were presented as frequency (f), percentage (\%), arithmetic mean $(\overline{\mathrm{X}})$ and standard deviation (SS). Pearson Correlation Coefficient, Simple and Muliple Regression Analysis were used for the relationship between variables. The SPSS package software was utilized for analyses of collected data; and 
significance was determined as $\mathrm{p}<0.05$.

\section{Results}

Table 2 shows there was a positive and significant relationship between the self-control and self-management skills with the level of hope scores of the coaches $(p<0.01)$. There was a high, negative and significant correlation between self-control and self-management skills with perceived stress scores of coaches $(p<0.01)$. In addition, there was a high, negative and significant correlation between perceived stress scores and level of hope scores of coaches $(\mathrm{p}<0.01)$.

Table 2. Correlation test results regarding the relation between "Self-Control and Self-Management", "Hope Level" and "Perceived Stress" variables

\begin{tabular}{llllll}
\hline Variables & $\overline{\mathrm{X}}$ & $\mathrm{SS}$ & 1 & 2 & 3 \\
\hline 1. Self-Control/Self-Management & 5.21 & 1.01 & 1 & & \\
2. Hope Level & 15.42 & 0.92 & $0.006^{* *}$ & 1 & \\
3. Perceived Stress & 3.36 & 1.15 & $-0.019^{*}$ & -0.316 & 1 \\
\hline
\end{tabular}

Note. $\mathrm{p}<0.05^{*}, \mathrm{p}<0.01^{* *}$.

Tables 3 to 6 show the regression analysis, the level of hope of the coaches on self-control and self-management $(\mathrm{F}=37.962)$; on the level of self-control and self-management of coaches $(\mathrm{F}=35.054)$; stress perceived by coaches was seen as a significant predictor of hope level $(\mathrm{F}=21.566, \mathrm{p}<0.01)$. Moreover, it was seen that perceived stress and self-control and self-management were a significant predictor of the level of hope of coaches $(\mathrm{F}=22.357, \mathrm{p}<0.01)$.

Table 3. Regression test results regarding the relation between "Self-Control/Self-Management" and "Hope Level" variables

\begin{tabular}{lllllllll}
\hline Variables & & \multicolumn{3}{l}{ Model Summary } & \multicolumn{3}{l}{ Anova } & \multicolumn{3}{l}{ Coefficients } \\
\hline Constant & Dependent & $R^{2}$ & $R$ & $F$ & $p$ & $\beta$ & $t$ & $p$ \\
Hope Level & Self-Control/ & 0.164 & 0.405 & 37.962 & 0.001 & 2.39 & 4.011 & 0.001 \\
& Self-Management & & & & & 0.57 & 6.161 & 0.001 \\
\hline
\end{tabular}

Note. Y (Self-Control/Self-Management) $=2.39+0.57$ (Hope Level).

Table 4. Regression test results regarding the relation between "Hope Level" and "Self-Control/Self-Management" variables

\begin{tabular}{lllllllll}
\hline Variables & & \multicolumn{2}{l}{ Model Summary } & \multicolumn{2}{l}{ Anova } & \multicolumn{3}{l}{ Coefficients } \\
\hline Constant & Dependent & $R^{2}$ & $R$ & $F$ & $p$ & $\beta$ & $t$ & $p$ \\
\hline Self-Control/ & Hope Level & 0.354 & 0.595 & 35.054 & 0.001 & 0.372 & 0.634 & 0.001 \\
Self-Management & & & & & & 0.252 & 6.080 & 0.001 \\
\hline
\end{tabular}

Note. Y $($ Hope Level) $=0.372+0.252$ (Self-Control/Self-Management).

Table 5. Regression test results regarding the relation between "Hope Level" and "Perceived Stress" variables

\begin{tabular}{lllllllll}
\hline Variables & & \multicolumn{2}{l}{ Model Summary } & \multicolumn{2}{l}{ Anova } & \multicolumn{3}{l}{ Coefficients } \\
\hline Constant & Dependent & $R^{2}$ & $R$ & $F$ & $p$ & $\beta$ & $t$ & $p$ \\
\hline Perceived Stress & Hope Level & 0.100 & 0.316 & 21.566 & 0.001 & 6.267 & 32.524 & 0.001 \\
& & & & & & -0.251 & -4.644 & 0.001 \\
\hline
\end{tabular}

Note. $\mathrm{Y}($ Hope Level) $=6.267-0.251$ (Perceived Stress $)$.

Table 6. Correlation test results regarding the relation between "Hope Level", "Perceived Stress" and "Self-Control/Self-Management" variables

\begin{tabular}{lllllllll}
\hline Variables & & \multicolumn{2}{l}{ Model Summary } & Anova & \multicolumn{3}{l}{ Coefficients } \\
\hline Constant & Dependent & $R^{2}$ & $R$ & $F$ & $p$ & $\beta$ & $t$ & $p$ \\
\hline Self-Control/ & Hope Level & 0.188 & 0.434 & 22.357 & 0.001 & 4.686 & 11.979 & 0.001 \\
Self-Management & & & & & & 0.234 & 4.575 & 0.017 \\
Perceived Stress & & & & & & -0.138 & -2.411 & 0.001 \\
\hline
\end{tabular}

Note. Y $($ Hope Level) $=4.686+0.234$ (Self-Control/Self-Management) -0.138 (Perceived Stress). 


\section{Discussion}

Hope is an important way of thinking that guides human life. When we think that this thought is formed from childhood, the studies with children are considered important. Therefore, the development and acquisition of hopeful ideas will make children more ready for life. In our country, there are studies about the level of hope of students (Akman \& Korkut, 1993; Denizli, 2004; Kemer, 2006; Kemer \& Atik, 2005), however, there is no study on the level of hope of coaches.

Self-control and self-management contribute to one's hope. Self-control and self-management are an optimistic construct. Coaches who are self-control and self-management can deal with potential stressors effectively. On the contrary, coaches who suspect their own abilities to control stressful events suffer more distresses which may impair their level of functioning. In light of this, high self-control and self-management coaches incline to perceive stressful events and obstacles with less apprehension and may regard this as a good chance for them to prove themselves. The results of this study demonstrated that high self-control and self-management coaches incline to create more agency thinking to pursue goal, or more pathways thinking to generate alternative paths to succeed. Other research also supported that high self-control and self-management affects how person cope with negative events (Asselmann et al., 2016). High self-control coaches are able to generate more pathways and agency thinking than low self-control and self-management coaches.

Stress is an important mediator in the association between self-control and self-management with hope. Improving self-control and self-management enables coaches to employ high hope to combat with stressors. On the other hand, coaches who lacked hopeful thinking often failed to work with high self-control and self-management. Support our findings, McGregor indicated that achievable goals are associated with well-being (McGregor \& Little, 1998).

The findings showed a high and positive relationship between the self-control and self-management skills of the coaches with the level of hope. In a similar study, a linear relationship was found between hope, self-control and subjective well-being (Liu, Zeng, \& Quan, 2018). Accordingly, as the self-control and self-management skills increases, levels of hope increase. Previous research has contributed to our study (Magaletta \& Oliver, 1999; Salanova, Lorente, Chambel, \& Martínez, 2011) in the sense that hope is a powerful psychological mechanism that partially mediates the link between self-control and stress, at least among coaches.

According to our findings, there was a high, negative and significant relationship between the self-control and self-management skills of the coaches with the perceived stress. Accordingly, as the self-control and self-management skills increase, perceived stress levels decrease.

Research has shown that self-control and self-management are negatively correlated with anxiety (Mezo, 2009), stress (Martin \& Tesser, 1989), aggression (Baumeister, Smart, \& Boden, 1996; Tice \& Baumeister, 1993; Zillman, 1993), and depression (Wenzlaff, Wegner, \& Roper, 1988). The findings are consistent with some research results.

In addition, there was a high, negative and significant relationship between the perceived stress of the coaches with level of hope. Accordingly, as the perceived stress levels decreases, self-control and self-management skills increase. As a result of a similar study, daily hope provides protective benefits by keeping negative emotions low, while also contributing to recovery from stress. The dynamic linkages between hope, stress, and emotion were further moderated by individual differences in hope. Compared with those low in hope, high-hope individuals showed diminished stress reactivity and more effective emotional recovery (Ong, Edwards, \& Bergeman, 2006). The findings are consistent with some research results.

In conclusion, this investigation shows that perceived stress affects self-control and self-management directly. Coachs high in perceived stress are more likely to be low in self-control and self-management. Therefore, the current findings increase our understanding of the relationships between self-control and self-management and perceived stress.

This study is interesting and has implications for interventions that can reduce perceived stress. The limitation of the study was that the participants were physical education teachers and this study should be replicated to target other coach populations in order to establish a more robust relationship between the examined structures, because the generalization of the results is somewhat limited.

\section{References}

Akın, A., Demirci, I., \& Çardak, M. (2012). The validity and reliability of the Turkish version of the Self-control and self-management Scale. Paper presented at the International Interdisciplinary Social Inquiry Conference - IISIC, June, 17-21, Bursa, Turkey. 
Akman, Y., \& Korkut, F. (1993). A Study on The Hope Scale. Journal of Hacettepe University Faculty of Education, 9, 193-202.

Anshel, M. H. (2003). Sport Psychology: From Theory to Practice (4th ed.). San Francisco, CA: Benjamin Cummings.

Asselmann, E., Wittchen, H. U., Lieb, R., Höfler, M., \& Beesdo-Baum, K. (2016). Does Low Coping Efficacy Mediate the Association Between Negative Life Events and Incident Psychopathology? A Prospective-Longitudinal Community Study Among Adolescents and Young Adults. Epidemiology \& Psychiatric Sciences, 25(2), 1-10. https://doi.org/10.1017/S204579601500013X

Baltaş, A., \& Baltaş, Z. (2002). Stress and Coping Ways (21st ed., pp. 323-327). Istanbul: Remzi Press.

Bandura, A. (1991). Social Cognitive Theory of Self-regulation. Organizational Behavior and Human Decision Processes, 50(2), 248-287. https://doi.org/10.1016/0749-5978(91)90022-L

Barrow, J. (1977). The Variables of Leadership: A Review and Conceptual Framework. Academy of Management Review, 2, 231-251. https://doi.org/10.5465/amr.1977.4409046

Bass, B. M. (1985). Leadership and Performance Beyond Expectations. New York: Free Press.

Baumeister, R., Smart, L., \& Boden, J. (1996). Relation of Threatened Egotism to Violence and Aggression: The Dark Side of High Self Esteem. Psychology Review, 103, 5-33. https://doi.org/10.1037/0033-295X.103.1.5

Bilge, A., Öğce, F., Genç, R. E., \& Oran, N. T. (2009). Psychometric Compatibility of The Turkish Version of The Perceived Stress Scale. Journal of Ege University School of Nursing, 25(2), 61-72.

Budak, G., \& Sürgevil, O. (2005). An Application on Academic Staff on the Analysis of Organizational Factors Affecting Burnout and Burnout. D.E.Ü.I.I. B.F. Journal, 20(2), 95-108.

Cohen, S., Kamarck, T., \& Mermelstein, R. (1983). A Global Measure of Perceived Stress. Journal of Health and Social Behavior, 24(4), 385-396. https://doi.org/10.2307/2136404

Denizli, S. (2004). The Role of Hope and Study Skills in Predicting Test Anxiety Levels of University Students. Unpublished Master Thesis, Middle East Technical University, Social Sciences Institute, Ankara.

Doğan, O. (2004). Sport Psychology Textbook (pp. 109-113). Sivas: Cumhuriyet University Publications.

Erci, B. (2006). Reliability and valididy of the Turkish version of perceived stress scale. Journal of Anatolia Nursing and Health Sciences, 9(1), 58-63.

Güney, S. (2001). Coping with Stress and Stress: Management and Organization (pp. 515-541). Ankara, Nobel Press.

Kanfer, F. H., \& Karoly, P. (1972). Self-control: A behavioristic excursion into the lion's den. Behavior Therapy, 3(3), 398-416. https://doi.org/10.1016/S0005-7894(72)80140-0

Kanfer, F. H., \& Schefft, B. K. (1988). Guiding the process of therapeutic change. Champaign, IL: Research Press.

Kemer, G. (2006). The role of self-efficacy, hope, and anxiety in predicting university entrance exam scores of eleventh-year students. Unpublished master's thesis, Middle East Technical University, Ankara.

Kemer, G., \& Atik, G. (2005). Comparison of hope levels of high school students in rural and urban areas according to perceived social support level from family. VIII. National Psychological Counseling and Guidance Congress. 21-23 September, İstanbul.

Liu, R., Zeng, P., \& Quan, P. (2018). The Role of Hope and Self-efficacy on Nurses' Subjective Well-being. Asian Social Science, 14(4), 18-22. https://doi.org/10.5539/ass.v14n4p18

Magaletta, P. R., \& Oliver, J. M. (1999). The hope construct, will, and ways: their relations with self-efficacy, optimism, and general well-being. Journal of Clinical Psychology, 55(5), 539-551. https://doi.org/10.1002/(SICI)1097-4679(199905)55:5<539::AID-JCLP2>3.0.CO;2-G

Martin, L. L., \& Tesser, A. (1989). Toward a motivational and structural theory of ruminative thought. In J. S. Uleman \& J. A. Bargh (Eds.), Unintended Thought (pp. 306-326). New York: Guilford Press.

McGregor, I., \& Little, B. R. (1998). Personal Projects, Happiness, and Meaning: on Doing Well and Being Yourself. J. of Personality \& Social Psy, 74(2), 494-512. https://doi.org/10.1037/0022-3514.74.2.494

Mezo, P. G. (2009). The Self-Control and Self-Management Scale (SCMS): Development of an adaptive self-regulatory coping skills instrument. Journal of Psychopathology and Behavioral Assessment, 31(2), 
83-93. https://doi.org/10.1007/s10862-008-9104-2

Norfolk, D. (1989). Stress in business life (Eds: Serdaroğlu L., pp. 3-12). İstanbul: Form Press.

Ong, A. D., Edwards, L. M., \& Bergeman, C. S. (2006). Hope as a Source of Resilience in Later Adulthood. Personality and Individual Differences, 41, 1263-1273. https://doi.org/10.1016/j.paid.2006.03.028

Rehm, L. P. (1977). A Self-Control Model of Depression. Behavior Therapy, 8(5), 787-804. https://doi.org/10.1016/S0005-7894(77)80150-0

Salanova, M., Lorente, L., Chambel, M. J., \& Martinez, I. M. (2011). Linking Transformational Leadership to Nurses \& Rsquo; Extra-Role Performance: The Mediating Role of Self-Efficacy and Work Engagement. Journal of Advanced Nursing, 67(10), 2256-2266. https://doi.org/10.1111/j.1365-2648.2011.05652.x

Snyder, C. R., Feldman, D. B., Shorey, H. S., \& Rand, K. L. (2002). Hopeful choices: A school counselor's guide to hope theory. Professional School Counseling, 5(5), 298-307.

Snyder, C. R., Harris, C., Anderson, J. R., Holleran, S. A., Irving, L. M., \& Sigmon, S. T. (1991). The will and the ways: Development and validation of an individual-differences measure of hope. Journal of Personality and Social Psychology, 60, 570-585. https://doi.org/10.1037/0022-3514.60.4.570

Snyder, C. R., Rand, K. L., \& Sigmon, D. R. (2002). Hope theory: A member of the positive psychology family. In C. R. Snyder \& S. J. Lopez (Eds.), Handbook of Positive Psychology (pp. 257-276). NY: Oxford University Press.

Snyder, C. R., Shorey, H. S., Cheavens, J., Pulvers, K. M., Adams, V. H., \& Wiklund, C. (2002). Hope and Academic Success in College. Journal of Educational Psychology, 94(4), 820-826. https://doi.org/10.1037/0022-0663.94.4.820

Simsek, Z., Heavey, C., \& Veiga, J. J. F. (2010). The Impact of CEO Core Self-evaluation on The Firm's Entrepreneurial Orientation. Strategic Management Journal, 31(1), 110-119. https://doi.org/10.1002/smj.800

Tice, D. M., \& Baumeister, R. F. (1993). Controlling anger: Self-induced emotion change. In D. M. Wegner \& J. W. Pennebaker (Eds.), Handbook of mental control (pp. 393-409). Englewood Cliffs, NJ: Prentice Hall.

Vilaythong, A. P., Arnau, R. C., Rosen, D. H., Mascaro, N. (2003). Humor and hope: Can humor increase hope? Humor, 16(1): 79-89. https://doi.org/10.1515/humr.2003.006

Wenzlaff, R. M., Wegner, D. M., \& Roper, D. W. (1988). Depression and mental control: the resurgence of unwanted negative thoughts. $J$ Pers Soc Psychol, 55(6), 882-892. https://doi.org/10.1037/0022-3514.55.6.882

Yukl, G. A. (1981). Leadership in Organizations (pp. 1-25). New Jersey: Prentice-Hall Int. Edit.

Zillman, D. (1993). The Mental Control of Angry Aggression. In D. M. Wegner \& J. W. Pennebaker (Eds.), Handbook of Mental Control (pp. 370-392). Englewood Cliffs, NJ: Prentice Hall.

\section{Copyrights}

Copyright for this article is retained by the author, with first publication rights granted to the journal.

This is an open-access article distributed under the terms and conditions of the Creative Commons Attribution license (http://creativecommons.org/licenses/by/4.0/). 